\title{
STRUCTURAL REMEDIATION OF AN ALFISOL BY MEANS OF SEWAGE SLUDGE AMENDMENTS IN ASSOCIATION WITH YELLOW SERRADELA (Ornithopus compressus L.)
}

\author{
M.A. Sandoval ${ }^{1 *}$, J.E. Celis ${ }^{2}$ and P. Morales ${ }^{1}$ \\ ${ }^{1}$ Departamento de Suelos y Recursos Naturales, Facultad de Agronomía, Universidad de \\ Concepción, Av. Vicente Méndez 595, Chillán, Chile. ${ }^{2}$ Departamento de Ciencias Pecuarias, \\ Facultad de Ciencias Veterinarias, Universidad de Concepción, Av. Vicente Méndez 595, \\ Chillán, Chile. *Corresponding author: masandov@udec.cl
}

\begin{abstract}
Wastewater treatment generates large amounts of sewage sludge, which when are disposed in highly degraded soils (with a complete loss of the A horizon and a great part of the B horizon), represent an interesting alternative to recover the aggregate level into soil. Within the hierarchy of soil systems, the aggregate level is the one that integrates soil properties that are directly related to soil sustainability. The aim of this study was to determine the effect of different dose of sewage sludge and an annual legume on the structural recovery of a degraded Alfisol. Sludge was added to soil at $0,15,30$ and $60 \mathrm{t}$ $\mathrm{ha}^{-1}$ in treatments with and without yellow serradela (Ornithopus compressus L.). After 6 months, the following structural indicators were identified: aggregate distribution, water aggregate stability and bulk density (Da). Results showed that the higher the sludge dose the higher the proportion of macroaggregates and their stability, whereas Da decreased. In spite of the short-term study, data showed that there was a positive effect when amendments were combined with $O$. compressus L. It demonstrated that degradation is likely to be reversed, thus giving to soil more physical support.
\end{abstract}

Keywords: Biosolids, degraded soils, soil remediation, physical properties.

\section{INTRODUCTION}

The generation of large quantities of waste from urban activities and different types of agricultural, industrial and waterrelated activities, is a concern to environmentalists, farmers and government agencies (Pinochet et al., 2004).

Wastewater treatments generate huge amounts of sewage sludge as a result of mechanical, biological and/or chemical treatments applied to these wastes, which are generically called municipal sludge (Marambio and Ortega, 2003; Aguilera et al., 2005). At a national level, water treatment plants generate around 220,000 tons of sludge yearly (Carrasco et al., 2004). Therefore, sludge disposal is a key issue that may result in a severe problem in the environment. Estimations indicate that, by the end of this decade, wastewater treatment in Chile will be in place in almost very city of the country, 
generating only in Santiago about 400 tons of sludge per day (Marambio and Ortega, 2003). Under these circumstances, it is clear that failure to seek disposal alternatives we will be facing a serious environmental problem.

Different alternatives for the disposal of such waste have been proposed at the international level, including the option of recycling waste in agricultural soils (Fytili and Zabaniotou, 2008; Fernández et al., 2007), as a way to help degraded soils restore their productivity (Esparza et al., 2004; Schleef et al., 2004; Aravena et al., 2007; Lakhdar et al., 2010). It is important to note that at least $46 \%$ of the Chilean agricultural area (34.5 million hectares) has certain degree of erosion of which $33 \%$ is severely affected (Esparza et al., 2004). The interior drylands of the Chilean Coastal Mountain, which are mainly constituted by Alfisols, are one of Chile's most eroded natural regions, with around 2 million hectares highly degraded (University of Chile, 2000). Intensive farming has accelerated this destructive process due to the use of inappropriate practices that severely reduce organic matter, resulting in a decrease of soil quality and unviable conditions for crop production (Celis et al., 2007; Curaqueo et al., 2010).

Sludge applications to degraded farmlands help improving soil productivity by increasing $\mathrm{pH}, \mathrm{OM}$ and the levels of N, P and K (Aravena et al., 2007, Gallardo et al., 2007, Celis et al. , 2008). Increased levels of OM tend to promote physical parameters such as soil aggregation and porosity (Darwish et al., 1995; Sandoval et al., 2008; Sandoval et al., 2010), also improving the environment for roots and plant growth (Ellies, 2004). Studies conducted on soils with applications of up to $5 \%$ of sewage sludge increased up to $78 \%$ aggregate stability as compared to the initial condition of the soil (Guerrero et al.,
2001). This provides evidence that sludge applications exert a protective effect against erosion (Roldán et al., 1996).

Recent research has been done with forage species possible to be adapted to drylands, thus reducing soil degradation problems in the same area under study. Among studied species, it is worth mentioning the annual legume Ornithopus compressus L. This legume presents good prospects to be integrated in the interior drylands (Ovalle et al., 2005), since these terrestrial environments require species and crops able to survive and reach adequate levels of production under acid conditions and low levels of organic matter. Existing data (Ovalle et al., 2006; Del Pozo and Ovalle, 2009) provide evidence that this legume shows better adaptation than native clover usually used on the area. Covering soil with crops have been described as a sustainable alternative for soil management because it allows increasing $\mathrm{OM}$ and nutrients in soil profile due to degradation of aboveground and root biomass, as well as improving porosity, soil structure and stability of aggregates (Ovalle et al., 2007). This is also supported by Bronick and Lal (2005) who suggest that well managed crops increase $\mathrm{C}$ inputs, so reducing erosion. Therefore, the aims of this study was to determine the effect of different application rates of sewage sludge and yellow serradela's roots on the structural remediation of a degraded Alfisol.

\section{MATERIALS AND METHODS}

\section{Soil and sludge sampling}

Soil samples were taken from the interior drylands of the Bío-Bío Region $\left(36^{\circ} 37\right.$ '18.6 "S, $\left.72^{\circ} 19^{\prime} 42.2^{\prime \prime} \mathrm{W}\right)$ at $0-20 \mathrm{~cm}$ deep. Soil taxonomic classification 
corresponded to a fine, kaolinitic, thermic Ultic Palexeralfs, clayed soil, slopes higher than $15 \%$, having a bulk density of $1.6 \mathrm{~g} \mathrm{~cm}^{-3}$ (Stolpe et al., 2008). These Alfisols are severely degraded by aggressive agricultural practices, with a complete loss of horizont $\mathrm{A}$ and almost all of horizont B.

Sewage sludge samples were taken at the wastewater plant of the city of Chillán $\left(36^{\circ} 36\right.$ 'S, 72 $\left.07^{\circ} \mathrm{W}\right)$. Sludge was produced from mechanically aerated biological reactors, having a capacity of 500 to $600 \mathrm{t}$ of fresh sludge $(80 \%$ humidity) monthly.

\section{Soil and sludge characterization}

Prior to the preparation of mixtures, soil and sludge samples were dried at room temperature in laboratory, and then sieved $(2 \mathrm{~mm})$ to allow homogenization of the material. After that, a representative sample for each sludge and soil was taken for chemical characterization (Table 1).

Table 1. Initial chemical characterization of the Alfisol and sewage sludge.

\begin{tabular}{lccc}
\hline & Units & Soil & $\begin{array}{c}\text { Sewage } \\
\text { sludge }\end{array}$ \\
\hline $\mathrm{pH}\left(\mathrm{H}_{2} \mathrm{O}\right)$ & & 5.60 & 5.94 \\
$\mathrm{MO}$ & $\%$ & 2.53 & 41.95 \\
$\mathrm{NO}_{3}-\mathrm{N}$ & $\mathrm{mg} \mathrm{kg}^{-1}$ & 6.50 & 17.1 \\
$\mathrm{NH}_{4}-\mathrm{N}$ & $\mathrm{mg} \mathrm{kg}^{-1}$ & 3.30 & 424.0 \\
Olsen-P & $\mathrm{mg} \mathrm{kg}^{-1}$ & 5.40 & 853.2 \\
$\mathrm{~K}$ available & $\mathrm{mg} \mathrm{kg}^{-1}$ & 29.80 & 5.591 .0 \\
Sum of bases & $\mathrm{cmol} \mathrm{kg}^{-1}$ & 5.47 & 42.67 \\
$\mathrm{Al}$ exchangeable & $\mathrm{cmol} \mathrm{kg}^{-1}$ & 0.02 & 0.01 \\
$\mathrm{CICE}$ & ${\mathrm{cmol}(+) \mathrm{kg}^{-1}}_{\mathrm{S}}$ & 5.49 & 42.7 \\
$\mathrm{~S}$ available & $\mathrm{mg} \mathrm{kg}^{-1}$ & 1.70 & 24.6 \\
$\mathrm{Fe}$ available & $\mathrm{mg} \mathrm{kg}^{-1}$ & 8.30 & 836.0 \\
$\mathrm{Mn}$ available & $\mathrm{mg} \mathrm{kg}^{-1}$ & 7.60 & 204.0 \\
$\mathrm{Zn}$ available & $\mathrm{mg} \mathrm{kg}^{-1}$ & 1.00 & 216.0 \\
$\mathrm{Cu}$ available & $\mathrm{mg} \mathrm{kg}^{-1}$ & 2.00 & 4.8 \\
$\mathrm{~B}$ available & $\mathrm{mg} \mathrm{kg}^{-1}$ & 0.10 & 10.6 \\
Total N & $\%$ & 0.15 & 5.47 \\
$\mathrm{C} / \mathrm{N}$ & & 9.3 & 4.5 \\
\hline
\end{tabular}


Methodology for soil chemical characterization was in accordance with Sadzawka et al. (2006) by using composed samples. Additionally, methods recommended by Sadzawka et al. (2005) were used for the sludge chemical characterization.

\section{Assay establishment}

The assay was conducted in a glass greenhouse located at the experimental field of the Faculty of Agronomy of the University of Concepción, Campus Chillán. The treatments were as follows: $\mathrm{CS}=$ non amended soil, no legume; CS-P $=$ non amended soil, cropped with legume; LU15 = soil amended with $15 \mathrm{t}$ ha $^{-1}$ sludge; LU15-P = soil amended with $15 \mathrm{t} \mathrm{ha}^{-1}$ sludge and cropped with legume; LU30 = soil amended with $30 \mathrm{t} \mathrm{ha}^{-1}$ sludge; LU30-P = soil amended with $30 \mathrm{t}$ $\mathrm{ha}^{-1}$ sludge and cropped with legume; LU60 = soil amended with $60 \mathrm{t} \mathrm{ha}^{-1}$ sludge; LU60-P = soil amended with $60 \mathrm{t}$ $\mathrm{ha}^{-1}$ sludge and cropped with legume.

Treatments with legume were established on the basis of 9 pots per treatment, 3 of which were used to determine soil aggregation, 3 for bulk density determination, and 3 for root biomass. Treatments without legume were established in 6 pots per treatment, 3 of which were used to determine soil aggregation, whereas 3 for bulk density and total porosity.

Sludge/soil mixtures were prepared on the basis of $1 \mathrm{~kg}$ of soil plus the corresponding sludge dose applied to each pot. Then they were mixed, homogenized and moistened with distilled water to reach $60 \%$ field capacity (soil moisture $\mathrm{H}$ $20 \mathrm{~mA}$ transmitter, Dragon Device). Each pot was then covered with polyethylene bags to prevent moisture loss and so kept for a month in order to standardize OM mineralization. Treatments were sown on August 20, 2009, with disinfected seeds of yellow serradela $\left(1.5 \mathrm{~g} \mathrm{pot}^{-1}\right)$. The assay lasted 6 months, through which soil moisture was maintained between $60-70 \%$ field capacity. Humidity was controlled by means of sensors (soil moisture H-20 $\mathrm{mA}$ transmitter, Dragon Device) and watered with distilled water. The average temperature ranged between 7 and $10^{\circ} \mathrm{C}$.

\section{Determination of structural characteristics}

At the end of the experiment, all pots were air-dried for 10 days. Samples from each treatments were taken from the 3 pots selected to measure bulk density, which was determined by using metal cylinders $(3.5 \times 5 \mathrm{~cm})$. These samples were then oven-dried $\left(105^{\circ} \mathrm{C}\right)$ until reaching constant weight (Blake and Hartge, 1986.)

Root biomass was determined in the other 3 pots for each treatment cropped with legume. Each pot was gently washed with water over a $0.5 \mathrm{~mm}$ sieve to collect biomass. Collected roots were air-dried just to eliminate excess of water and then placed into holed-paper bags, so being oven dried $\left(60^{\circ} \mathrm{C}, 48 \mathrm{~h}\right)$. Root biomass was calculated by gravimetry

Both aggregates and their stability were determined from the remaining 3 pots per each treatments. It was done by gently breaking up the soil and passing it through a $4.5-\mathrm{mm}$ sieve (Le Bissonnais, 1996). Then, a 100-g sample per each replicate was selected and transferred to a set of sieves of different diameters $(2,1$, $0.5,0.25$ and $0.05 \mathrm{~mm}$ ). The sieves with the soil sample were immersed in water for $5 \mathrm{~min}$ and then agitated for $15 \mathrm{~min}$ at 25 cycles $\min ^{-1}$ (Yoder, 1936).

Due to the presence of a large amount of gravel in these soils, the sand fraction was removed from all samples analyzed, according to the procedure described by Sandoval et al. (2010). To achieve it, once the dry mass was determined, the 
resulting aggregate content of each sieve was immersed for $24 \mathrm{~h}$ in a solution of $0.5 \mathrm{~N} \mathrm{NaOH}(50 \mathrm{~mL})$. After that, the sample was agitated about 2 minutes at 15,000 cycles $\mathrm{min}^{-1}$, and then particles were separated by a constant flow of water. Once sand fraction was separated, the sample was dried $\left(105^{\circ} \mathrm{C}, 24 \mathrm{~h}\right)$, thus mass was deducted from the initial weight of the aggregates contained in each sieve. The aggregate percentage was calculated using the following expression:

$$
\text { [1] } A G_{i}=\frac{\left(M A_{i}-M a_{i}\right)}{W}
$$

where: $A_{\mathrm{i}}$ is the percentage of aggregate of the sieve $\mathrm{i}$ (sand fraction deducted), $\quad \mathrm{MA}_{\mathrm{i}}$ is the mass of aggregates and sand retained by the sieve $i, M_{i}$ is the mass of sand of the sieve $\mathrm{i}, \mathrm{W}$ is the total mass of soil evaluated. Mean weight diameter (MWD) was determined by using the procedure described by Kemper and Rosenau (1986).

\section{Experimental design}

The experimental design was a completely randomized design with a factorial arrangement of $2 \times 4$ (legume $\mathrm{x}$ rates of sludge application). The results for the physical parameters were analyzed using the analysis of variance ANOVA $(p \leq 0.05)$. When finding significant differences between treatments, means were separated according to Tukey's test (SAS, 1999).

\section{RESULTS AND DISCUSION}

\section{Bulk density and porosity}

The result of analysis of variance (Table 2) for bulk density and porosity indicates that the interaction between both factors, legume and sludge dose, was not significant.

When analyzing the treatments (Table 3 ), differences were found between the highest application rate $\left(60 \mathrm{t} \mathrm{ha}^{-1}\right)$ and control (CS) for both $\mathrm{Da}$ and $\mathrm{Pt}$ in cropped treatments. No cropped treatments showed only significant differences $(p \leq 0.05)$ for $\mathrm{Da}$ when comparing LU30 with CS.

Comparatively, soil amended with sewage sludge and cropped with Ornithopus compressus L. had significantly lower values for $\mathrm{Da}$ and significantly higher $\mathrm{Pt}$ as compared with no cropped amended treatments. It is interesting to note that there was a remarkable effect when adding OM in presence of legume, as found by LU60-P (Table 3). Similarly, a study conducted in a Andisol located in the same region showed that Da decreased and $\mathrm{Pt}$ increased when plant residues were added to soil (Sandoval et al., 2008). The Da values obtained in this study are slightly lower than those reported by Stolpe et al. (2008) for the same area, which could be explained by the favorable effect of adding to soil sewage sludge in association with legumes. García-Orenes et al. (2005) stated the positive effects resulting from the application of sewage sludge, indicating that these residues improve soil structure by decreasing bulk density. Moreover, crops can increase $\mathrm{OM}$ and nutrients in soil's matrix due to 
Table 2. $\mathrm{F}$ values for bulk density $(\mathrm{Da})$, total porosity $(\mathrm{Pt})$, mean weight diameter (DPM) and sum of macroaggregates $\left(\sum \geq 0.25 \mathrm{~mm}\right)$.

\begin{tabular}{lcccc}
\hline Source of variation & $\begin{array}{c}\mathbf{D a} \\
\left(\mathbf{g ~ c m}^{-3}\right)\end{array}$ & $\begin{array}{c}\mathbf{P t} \\
(\mathbf{\%})\end{array}$ & $\begin{array}{c}\mathbf{D P M} \\
(\mathbf{m m})\end{array}$ & $\begin{array}{c}\sum \geq \mathbf{0 . 2 5} \mathbf{~ m m} \\
(\mathbf{\%})\end{array}$ \\
\hline Legume (A) & $17.24^{*}$ & $20.33^{*}$ & $74.01^{*}$ & $52.15^{*}$ \\
Sewage sludge dose (B) & $10.18^{*}$ & $10.28^{*}$ & $7.55^{*}$ & $8.89^{*}$ \\
A x B & $0.60^{\mathrm{ns}}$ & $0.50^{\mathrm{ns}}$ & $1.37^{\mathrm{ns}}$ & $1.16^{\mathrm{ns}}$ \\
\hline
\end{tabular}

*Significant $(p \leq 0.05)$; ns: not significant.

Table 3. Bulk density (Da), total porosity $(\mathrm{Pt})$ and organic matter (OM) for an Alfisol with different application rates of urban sludge with and without legume.

\begin{tabular}{lccc}
\hline Treatments & Da $\left(\mathbf{g ~ c m}^{-3}\right)$ & Pt (\%) & OM (\%) \\
\hline a) With legume & & & \\
CS-P & $1.53 \mathrm{a}$ & $43 \mathrm{~b}$ & $2.2 \mathrm{~b}$ \\
LU15-P & $1.39 \mathrm{ab}$ & $48 \mathrm{ab}$ & $2.4 \mathrm{~b}$ \\
LU30-P & $1.36 \mathrm{ab}$ & $49 \mathrm{ab}$ & $2.4 \mathrm{~b}$ \\
LU60-P & $1.30 \mathrm{~b}$ & $51 \mathrm{a}$ & $3.6 \mathrm{a}$ \\
b) Without legume & $1.61 \mathrm{a}$ & & $1.6 \mathrm{a}$ \\
CS & $1.53 \mathrm{a}$ & $39 \mathrm{~b}$ & $2.0 \mathrm{a}$ \\
LU15 & $1.44 \mathrm{a}$ & $42 \mathrm{ab}$ & $1.7 \mathrm{a}$ \\
LU30 & $1.45 \mathrm{a}$ & $46 \mathrm{a}$ & $2.2 \mathrm{a}$ \\
LU60 & $45 \mathrm{ab}$ & \\
\hline
\end{tabular}

$\mathrm{CS}=$ control (not amended); CS-P = soil + legume; LU15 = soil $+15 \mathrm{tha}^{-1}$ sludge; LU15-P = soil + 15 $\mathrm{t} \mathrm{ha}^{-1}$ sludge + legume; LU30 = soil $+30 \mathrm{t} \mathrm{ha}^{-1}$ sludge; LU30-P $=$ soil $+30 \mathrm{t} \mathrm{ha}^{-1}$ sludge + legume; LU60 = soil $+60 \mathrm{t} \mathrm{ha}^{-1}$ sludge; LU60-P $=$ soil $+60 \mathrm{tha}^{-1}$ sludge + legume. Different letters in same column indicate significant differences for treatments with legume and without legume separately $(p \leq$ $0.05)$.

degradation of biomass, improving the soil physical properties such as porosity, structure and aggregate stability (Frye and
Blevins, 1989), thus avoiding erosion and minimizing the dispersion of sludge to nearby areas. 
Stability and distribution of waterstable aggregates

Distribution of water-stable aggregates (Table 4) showed a predominance of macroaggregates $\left(\sum \geq 0.25 \mathrm{~mm}\right)$. It was observed that amended and cropped treatments showed significant differences $(p \leq 0.05)$ for macroaggregates and it corresponding stability (DPM). No cropped amended treatments showed significant differences $(p \leq 0.05)$ only at 30 and $60 \mathrm{t} \mathrm{ha}$ of sludge with respect to control (CS). These results showed that the presence of roots had a fundamental role in macroaggregate stability and in soil formation, which was more notorious when soil was amended with sewage sludge.

Table 4. Distribution of macroaggregates and mean weight diameter (DPM) for the Alfisol studied.

\begin{tabular}{|c|c|c|c|c|c|c|c|}
\hline \multirow{2}{*}{ Treatments } & \multicolumn{5}{|c|}{ Strainer size (mm) } & \multirow{2}{*}{$\begin{array}{c}\sum \geq 0.25 \\
\mathrm{~mm} \mathrm{\%}\end{array}$} & \multirow{2}{*}{$\begin{array}{l}\text { DPM } \\
(\mathrm{mm})\end{array}$} \\
\hline & $4-2$ & $2-1$ & $1-0.5$ & $0.5-0.25$ & $<0.25$ & & \\
\hline \multicolumn{8}{|c|}{ a) With legume } \\
\hline CS-T & 1.18 & 9.49 & 11.40 & 13.12 & 14.90 & $35.18 \mathbf{a}$ & $0.44 \mathbf{a}$ \\
\hline LU15-T & 4.47 & 8.39 & 13.22 & 10.09 & 10.48 & $36.17 \mathbf{a}$ & $0.59 \mathbf{a}$ \\
\hline LU30-T & 6.47 & 10.70 & 12.87 & 13.19 & 11.66 & $43.24 \mathbf{a}$ & $0.63 \mathbf{a}$ \\
\hline LU60-T & 4.22 & 14.95 & 14.00 & 8.88 & 13.95 & $42.06 \mathbf{a}$ & $0.60 \mathrm{a}$ \\
\hline $\mathrm{Cv}(\%)$ & & & & & & 10.14 & 14.76 \\
\hline \multicolumn{8}{|c|}{ b) Without legume } \\
\hline $\mathrm{CS}$ & 0.34 & 2.30 & 6.10 & 9.91 & 22.77 & $18.65 \mathbf{b}$ & $0.25 \mathrm{c}$ \\
\hline LU15 & 0.59 & 7.37 & 7.98 & 12.01 & 3.42 & $27.95 \mathbf{a b}$ & $0.40 \mathbf{a}$ \\
\hline LU30 & 0.77 & 4.37 & 10.83 & 16.86 & 23.07 & $32.82 \mathbf{a}$ & 0.32 bc \\
\hline LU60 & 0.50 & 7.37 & 9.71 & 12.26 & 5.25 & $29.84 \mathbf{a}$ & $0.39 \mathbf{a b}$ \\
\hline $\mathrm{Cv}(\%)$ & & & & & & 14.88 & 9.62 \\
\hline
\end{tabular}

$\mathrm{CS}=$ control (not amended); CS-P $=$ soil + legume; $\mathrm{LU} 15=$ soil $+15 \mathrm{t} \mathrm{ha}^{-1}$ sludge LU15-P $=$ soil + $15 \mathrm{tha}^{-1}$ sludge + legume; LU30 = soil $+30 \mathrm{tha}^{-1}$ sludge; LU30-P = soil $+30 \mathrm{t} \mathrm{ha}^{-1}$ sludge + legume; LU60 $=$ soil $+60 \mathrm{t} \mathrm{ha}^{-1}$ sludge; LU60-P $=$ soil $+60 \mathrm{t} \mathrm{ha}^{-1}$ sludge + legume; DPM $=$ mean weight diameter; $\mathrm{Cv}$ : variation coefficient. Different letters in same column indicate significant differences for treatments with legume and without legume separately $(p \leq 0.05)$.

Additionally, DPM values from amended and cropped treatments ranged from 0.44 to $0.60 \mathrm{~mm}$, so that no significant differences $(p>0.05)$ were found among treatments. In contrast, no cropped amended treatments showed significant differences $(p \leq 0.05)$ at 15 and $60 \mathrm{tha}^{-1}$ with respect to control (CS). In general, values were lower than cropped amended treatments, especially CS that showed a value of $0.25 \mathrm{~mm}$, a very unstable structural state (Le Bissonnais, 1996). 
This greater positive effect due to the contribution of $\mathrm{OM}$ in the presence of yellow serradela is clearly evidenced when analyzing the root biomass data (Table 5). The higher the dose amended to soil the higher the root development, being particularly different $(p \leq 0.05)$ from the control (CS-P).

Table 5. Root biomass for treatments amended with sewage sludge and cropped with yellow serradela (Ornithopus compressus L.).

\begin{tabular}{lc}
\hline Treatments & Root biomass (g) \\
\hline CS-P & $4.3 \mathbf{b}$ \\
LU15-P & $6.5 \mathbf{a}$ \\
LU30-P & $7.6 \mathbf{a}$ \\
LU60-P & $7.9 \mathbf{a}$ \\
CV (\%) & 11.0 \\
\hline
\end{tabular}

CS-P = not amended (only cropped); LU15-P = soil amended with $15 \mathrm{t} \mathrm{ha}^{-1}$ sludge and cropped with legume; LU30-P = soil amended with 30 t $\mathrm{ha}^{-1}$ sludge and cropped with legume; LU60-P = soil amended with $60 \mathrm{tha}^{-1}$ sludge and cropped with legume. $\mathrm{Cv}=$ variation coefficient. Different letters indicate significant differences $(p \leq 0.05)$.

According to Bronick and Lal (2005), both plant roots and rhizosphere have positive effects on soil aggregation because glue soil particles as their release exudates, which result in physical, chemical and biological changes that positively influence aggregation. Sandoval et al. (2007) found a positive response in the aggregation and stability of soil aggregates when legumes (pink clover, alfalfa and white clover) were incorporated to soil in a crop rotation that included wheat, oats and corn. In addition, they also reported that these legume species favored $\mathrm{C}$ content into the soil. Additionally, several authors have noted the importance of fungi in soils, as their hyphae are considered to be primary soil aggregators, showing positive correlations with stability of aggregates in natural systems (Borie et al ., 2008; Curaqueo et al., 2010).

Also, data showed the importance of adding sewage sludge to soil as it increased root biomass, which also improves soil structure, where organic $\mathrm{C}$ acts as a nucleus in the aggregate formation (Bronica and Lal, 2005). Sandoval-Estrada et al. (2008) indicated that the stability of macroaggregates varies with changes in $\mathrm{OM}$ content and management practices, due to the fact that macroaggregates are stabilized by agents such as roots, hyphae and polysaccharides. Furthermore, Oades and Waters (1991) refer to OM as one of the major factors in soil aggregation of Alfisols.

Haynes and Francis (1990) stated the importance of legume crop rotations on soil aggregation. This has been confirmed by several studies that indicate that legume roots increase soil microbial biomass, which generates an increase in water-stable aggregates (Chan and Heenan, 1996; Haynes and Beare, 1997).

\section{CONCLUSIONS}

Sewage sludge amendments improved soil structural properties of the degraded Alfisol studied. These improvements were the result of the contribution of soil organic matter, which resulted in a decrease of bulk density, and an increase of total porosity, macroaggregates and soil stability. This was directly related to the increase of amendment application rates. The establishment of Ornithopus compressus L. significantly enhanced 
these parameters due to increased root biomass. This demonstrated that it is possible to recover certain physical properties in highly degraded soils, under the conditions in which this research study was carried out.

\section{AKNOWLEDGEMENTS}

This work has been funded by the Research Division of the University of Concepción, through project DIUC 208.153.018-1.0.

\section{REFERENCES}

Aguilera, S., Borie, G., Peirano, P., Varnero, T. 2005. Residuos urbanos. En: S.M. Aguilera, M. Rodríguez (eds.). Desarrollo de prácticas sustentables de reciclaje de biosólidos en plantaciones forestales. Universidad de Chile. Facultad de Ciencias Forestales y Facultad de Ciencias Químicas y Farmacéuticas. Santiago, Chile, pp: 25-46.

Aravena C., Valentín, C., Diez, M.C., Mora, M.L., Gallardo, F. 2007. Aplicación de lodos de planta de tratamiento de celulosa: efecto en algunas propiedades físicas y químicas de suelos volcánicos. J. Soil Sci. Plant Nutr. 7, 1-14.

Blake, G.R., Hartge, K.H. 1986. Bulk density. In: A. Klute (ed). Methods of soil analysis, 2nd ed. ASA and SSSA. Madison, Wisconsin, USA, pp: 363-375.

Borie, F., Rubio, R., Morales, A. 2008. Arbuscular mycorrhizal fungi and soil aggregation. J. Soil Sci. Plant Nutr. 8, 9-18.

Bronick, C.J., Lal, R. 2005. Soil structure and management: a review. Geoderma 124, 3-22.

Carrasco, A., Ahumada, I., Castillo, G., Sadzawka, A., Pedraza, C., León, O. 2004. Absorción de $\mathrm{Cu}$ y $\mathrm{Zn}$ en ballica cultivada en suelos tratados con biosólidos. En: Residuos Orgánicos y su uso en Sistemas Agroforestales. Simposio de la Sociedad Chilena de la Ciencia del Suelo, Universidad de la Frontera, Temuco, pp. 295-303.
Celis, J., Sandoval, M., Briones, M. 2007. Bioensayos de fitotoxicidad de residuos orgánicos en lechuga y ballica anual realizados en un suelo Alfisol degradado. J. Soil Sci. Plant Nutr. 7, 51-56.

Celis, J., Sandoval, M., Barra, R. 2008. Salmon wastes and urban sludge as organic fertilizer for plant response on two Chilean degraded soils under greenhouse conditions. Chilean J. Agric. Res. 68, 274-283.

Chan, K.Y., Heenan, D.P. 1996. The influence of crop rotation on soil structure and soil physical properties under conventional tillage. Soil Tillage Res. 37, 113-125.

Curaqueo, G., Acevedo E., Cornejo P., Seguel A., Rubio R., Borie F. 2010. Tillage effect on soil organic matter, mycorrhizal hyphae and aggregates in mediterranean agroecosystem. J. Soil Sci. Plant Nutr. 10 (1), 12-21.

Del Pozo, A., Ovalle, C. 2009. Productivity and persistence of yellow serradela (Ornithopus compressus L.) and biserrula (Biserrula pelecinus $L$.) in the mediterranean climate region of central Chile. Chilean J. Agric. Res. 69 (3), 340-349.

Darwish, O.H., Persaud, N., Martens, D.C. 1995. Effect of long-term application of animal manure on physical properties of three soils. Plant Soil 176, 289-295.

Ellies, A. 2004. Efecto de la materia orgánica en el suelo. En: Residuos orgánicos y su uso en sistemas agroforestales. Simposio de la Sociedad Chilena de la Ciencia del Suelo, Universidad de La Frontera, Temuco, pp: 139150.

Esparza, J., Diez, M., Gallardo, F. 2004. Aplicación de lodos de la industria de celulosa a suelos Andisoles chilenos. En: Residuos Orgánicos y su uso en Sistemas Agroforestales. Simposio de la Sociedad Chilena de la Ciencia del Suelo, Universidad de la Frontera, Temuco, pp: 27-38.

Fernández, J.M., Plaza, C., Hernandez, D., Polo, A. 2007. Carbon mineralization in an arid soil amended with thermally-dried and composted urban sludges. Geoderma 137, 310317.

Frye, W.W., Blevins, R.L. 1989. Economically sustainable crop production with legume cover 
crops and conservation tillage. J. Soil Water Conserv. 44, 57-60.

Fytili, D., Zabaniotou, A. 2008. Utilization of urban sludge in EU application of old and new methods-A review. Renew. Sust. Energ. Rev. 12, 116-140.

Gallardo, F., Bravo C., Briceño G., Diez M.C. 2010. Use of sludge from Kraft mill wastewater treatment as improver of volcanic soils: Effect on soil biological parameters. J. Soil Sci. Plant Nutr. 10 (1), 48-61.

Gallardo, F., Mora, M.L., Diez M.C. 2007. Kraft mill sludage to improve vegetal production in Chilean Andisol. Water Sci. Technol. 55, 3137.

García-Orenes, F., Guerrero, C., MataixSolera, J., Navarro-Pedreño, J., Gómez, I., Matax-Beneyto, J. 2005. Factors controlling the aggregate stability and bulk density in two different degraded soils amended with biosolids. Soil Tillage Res. 82, 65-76.

Guerrero, C., Mataix-Solera, J., NavarroPedreño, J., García-Orenes, F. and Gómez, I. 2001. Different patterns of aggregate stability in burned and restored soils. Arid Land Res. Manag. $15,163-171$.

Haynes, R.J., Beare, M.H. 1997. Influence of six crop species on aggregate stability and some labile organic matter fractions. Soil Biol Biochem. 29, 1647-1653.

Haynes, R.J., Francis, G.S. 1990. Effects of mixed cropping farming systems on changes in soil properties on the Canterbury Plains. New Zeal. J. Ecol. 14, 73-82.

Hernández, T., Moreno, J.L., Costa, F. 1991. Influence of urban sludge application on crop yields and heavy metal availability. Soil Sci. Plant Nutr. 37, 201-210.

Kay, B. D. 1998. Soil structure and organic carbon: a review. In: R. Lal et al. (eds.). Soil Processes and the Carbon Cycle. CRC Press, Boca Raton, FL, pp: 169-197.

Kemper, W., Rosenau, R. 1986. Aggregate stability and size distribution. Agronomy. USA.

Lakhdar, A., Scelza R., Scotti R., Rao M.A., Jedidi, N., Gianfreda, L., Abdelly, C. 2010. The effect of compost and sewage sludge on soil biologic activities en salt affected. J. Soil Sci Plant Nutr. 10 (1), 40-47.

Le Bissonnais, Y. 1996. Aggregate stability and assessment of soil crustability and erodibility: I. Theory and methodology. Eur. J. Soil Sci. 47, 425-437.

Marambio, C., Ortega, R. 2003. Uso potencial de lodos derivados del tratamiento de aguas servidas en la producción de cultivos en Chile. Revista Agronomía y Forestal UC No 20, 20-23.

Oades, J.M., Waters, A.G. 1991. Aggregate hierarchy in soils. Aust. J. Soil Res 29, 815-828.

Ovalle, C., Del Pozo, A., Lavín, A., Hirzel, J. 2007. Cubiertas vegetales en viñedos: comportamiento de mezclas de leguminosas forrajeras anuales y efectos sobre la fertilidad del suelo. Chilean J. Agric. Res. 67 (4), 384-392.

Ovalle, C., Arredondo, S., Romero, O. 2006. Serradela amarilla (Ornithopus compressus) y Serradela rosada (O. sativus): dos nuevas especies de leguminosas forrajeras anuales para la Zona Mediterránea de Chile. Agric. Téc. 66, 196-209.

Ovalle, C., Del Pozo, A., Avendaño, J., Fernández, F. 2005. Adaptación, crecimiento y producción de nuevas leguminosas forrajeras anuales en la zona mediterránea de Chile. II. Comportamiento de las especies en suelos graníticos del secano interior subhúmedo. Agric. Téc. 65, 265-277.

Pinochet, D., De Armas, M., Solis, J., Aymans, D. 2004. Tasas de mineralización para nitrógeno y fósforo en lodos de salmonicultura y sanitarios. En: Residuos Orgánicos y su uso en Sistemas Agroforestales. Simposio de la Sociedad Chilena de la Ciencia del Suelo, Universidad de la Frontera, Temuco. Pp. 59-68.

Roldán, A., Albadalejo, J., Thornes, J. B. 1996. Aggregate stability changes in a semiarid soil after treatment with different organic amendments. Arid Soil Res. Rehab. 10, 139-148.

Sadzawka, R., Carrasco, M., Grez, R., Mora, M. 2005. Métodos de análisis de compost. Instituto de investigación Agropecuaria. Serie Actas INIA No 30 . INIA. Santiago, Chile.

Sadzawka, R., Carrasco, M., Grez, R., Mora, M., Flores, H., Neaman, A. 2006. Métodos de análisis recomendados para los suelos de Chile. Revisión 2006. Instituto de investigación 
Agropecuaria. Serie Actas INIA N ${ }^{\circ} 34$. INIA. Santiago, Chile.

Sandoval-Estrada, M., Celis-Hidalgo, J. Stolpe-Lau, N., Capulín-Grande, J. 2010 Efecto de las enmiendas con lodos urbanos y de salmonicultura en la estructura de un Entisol y un Alfisol en Chile. Agrociencia 44(5), 503 - 515.

Sandoval-Estrada, M., Stolpe-Lau, N., ZagalVenegas, E., Mardones-Flores, M., CelisHidalgo, J. 2008. Aporte de carbono orgánico de la labranza cero y su impacto en la estructura de un andisol de la precordillera andina chilena. Agrociencia 42, 139-149.

Sandoval, M., Stolpe, N., Zagal, E., Mardones M. 2007. The effect of crop-pasture rotations on the $\mathrm{C}, \mathrm{N}$ and $\mathrm{S}$ contents of soil aggregates and structural stability in a volcanic soil of southcentral Chile. Acta. Agr. Scand. Section B-Soil \& Plant Sci. 57, 255-262.

SAS Institute. 1999. SAS Release 8.1 Ed. SAS Institute, Inc. Cary, N. C. USA.

Schleef, E., Vergara, C., Diez, M. 2004 Evaluación de alternativas para la estabilización de biosólidos generados en un sistema de tratamiento de aguas servidas. En: Residuos Orgánicos y su uso en Sistemas Agroforestales. Simposio de la Sociedad Chilena de la Ciencia del Suelo, Universidad de la Frontera, Temuco. pp: 39-51.
Stolpe, N., Zagal, E., Sandoval, M., Quezada, C. 2008. The International Conference \& Field Workshops on Soil Classification. Departamento de Suelos y Recursos Naturales, Facultad de Agronomía, Universidad de Concepción, Chile.

Tang, C., Yu, Q. 1999. Impact of chemical composition of legume residues and initial soil $\mathrm{pH}$ on $\mathrm{pH}$ change of a soil after residue incorporation. Plant Soil 215, 29-38.

Universidad de Chile. 2000. Informe País: Estado del Medio Ambiente en Chile-1999. Centro de Análisis de Políticas Públicas, Universidad de Chile, LOM Ediciones, Santiago. $433 \mathrm{p}$.

Yoder R. 1936. A direct method of aggregate analysis and a study of the physical nature of erosion losses. J. Am. Soc. Agron. 28, 337-351.

Zufiaurre, R., Olivar, A., Chamorro, P., Nerín, C., Callizo, A. 1998. Speciation of metals in urban sludge for agricultural uses. Analyst 123, 255-259. 